\author{
GRZEGORZ MASIK \\ Uniwersytet Gdański, Polska \\ University of Gdańsk, Poland
}

\title{
Miary odporności gospodarczej, społecznej i instyłucjonalnej
}

\section{Measures of Economic, Social and Institutional Resilience}

Streszczenie: Przedmiotem pracy są miary odporności gospodarczej, społecznej i instytucjonalnej podejmowane w badaniach międzynarodowych. Celem opracowania jest natomiast przegląd międzynarodowych badań i na tej postawie przedstawienie stosowanych miar i wskaźników odporności. Do prezentacji wyników analizy wykorzystano zestawienia tabelaryczne uwzględniające kilka cech wskaźników. Z przeglądu literatury wynika, że w badaniach odporności wyróżnia się takie kategorie wskaźników, jak: wskaźniki kontekstowe, wskaźniki wejściowe, wskaźniki produktu, wskaźniki rezultatu oraz wskaźniki procesu. Inny podział wskaźników uwzględnia pomiar bezpośredni i pośredni odporności. Miary odporności mogą odnosić się również do wskaźników ilościowych i jakościowych. Odnosząc się do skali badania odporności, wyróżnia się poziom międzynarodowy, krajowy, regionalny, lokalny (miejski), sąsiedzki i indywidualny lub gospodarstw domowych. Z przeglądu badań wynika, że najczęściej w analizach odporności stosowane są wskaźniki produktu i rezultatu na poziomie krajowym i lokalnym. Zdecydowana większość wskaźników pozwala zmierzyć odporność w sposób pośredni, a metoda pomiaru ma zazwyczaj charakter ilościowy i opiera się na danych wtórnych.

\begin{abstract}
The subject of the paper are measures of economic, social and institutional resilience undertaken in many international studies. The aim of the study, however, is to review international research and on this basis to present the measures and indicators of resistance used. To present the results of the analysis, tables were used, taking into account several characteristics of indicators. A review of the literature shows that resilience studies distinguish categories of indicators such as: context/baseline indicators, input indicators, output indicators, outcome indicators and process indicators. Another division of indicators includes direct and indirect measurement of resilience. Resilience measures can also refer to quantitative and qualitative indicators. Referring to the scale of the research, the international, national, regional, local (urban), neighborhood and individual or household level are distinguished. A review of the studies shows that output and outcome indicators at national and local levels are most commonly used in resilience analyses. The vast majority of indicators allow to measure resilience indirectly and the measurement method is usually quantitative and based on secondary data.
\end{abstract}

Słowa kluczowe: miary; odporność gospodarcza; odporność instytucjonalna; odporność społeczna; wskaźniki

Keywords: economic resilience; indicators; institutional resilience; measures; social resilience 
Otrzymano: 4 grudnia 2019

Received: 4 December 2019

Zaakceptowano: 6 lutego 2020

Accepted: 6 February 2020

Sugerowana cytacja / Suggested citation:

Masik, G. (2020). Miary i wskaźniki odporności gospodarczej, społecznej i instytucjonalnej. Prace Komisji Geografii Przemysłu Polskiego Towarzystwa Geograficznego, 34(1), 32-48. doi: 10.24917/20801653.341.3

\section{WSTĘP}

Coraz częściej w debacie publicznej oraz badaniach międzynarodowych teoretycy i praktycy podejmują problem odporności systemów ekologicznych i społeczno-ekonomicznych na różnego rodzaju nagłe zmiany, w tym katastrofy ekologiczne, fale migracji, zmiany społeczne czy szoki gospodarcze. Przykładem może być raport przygotowany w związku ze szczytem klimatycznym Organizacji Narodów Zjednoczonych, który odbył się w Nowym Jorku we wrześniu 2019 roku. Mianowicie podkreśla się w nim wpływ zmian klimatycznych na osiąganie celów zrównoważonego rozwoju oraz potrzebę holistycznego zrozumienia społeczno-ekonomicznych konsekwencji ekstremalnych warunków pogodowych w państwach na całym świecie (WMO Statement, 2019). W raporcie zwraca się uwagę na wpływ zmian klimatycznych m.in. na zdrowie ludzkie, jakość życia, utratę miejsc pracy czy spadek produktywności pracy.

Nie tylko zmiany klimatyczne, lecz także procesy geopolityczne mogą powodować różnego rodzaju napięcia społeczne, a procesy globalizacji, finansjalizacji oraz informatyzacji mogą przyczyniać się do nagłych zmian społecznych oraz kryzysów gospodarczych. Stąd zrodziła się potrzeba zwrócenia większej uwagi na zagadnienie odporności, w tym adaptacyjności systemów społeczno-ekonomicznych. W pierwszym okresie przystąpiono do opracowania założeń koncepcyjnych (Christopherson, Michie, Tyler, 2010; Pike, Dawley, Tomaney, 2010; Simmie, Martin, 2010). Następnie przedmiotem studiów międzynarodowych były analizy układów regionalnych w kontekście kryzysu ekonomicznego (Martin, 2012; Di Caro, 2014). Również w Polsce na łamach „Prac Komisji Geografii Przemysłu Polskiego Towarzystwa Geograficznego" przystąpiono do tego rodzaju analiz (Zioło, Rachwał, 2011a, 2011b; Rachwał, 2011; Zioło, Rachwał, 2014; Masik, 2019). W związku z pojawieniem się licznych opracowań badawczych, uwzględniając krytykę koncepcji odporności (MacKinnon, Direckson, 2013; Gong, Hassink, 2017), przystąpiono do działań strategicznych, w tym implementacji koncepcji, wykorzystując do tego rozmaite miary. W konsekwencji rozwoju badań nad odpornością przystąpiono do opracowywania strategii, w tym zaczęto proponować wskaźniki polityki odporności o walorach aplikacyjnych. Swój wkład miała początkowo Rada Ministerialna OECD (2014a), która stworzyła ramy strukturalne dla badania poziomu odporności i wdrażanych strategii.

Zgodnie z jedną z wielu definicji odporność jest to zdolność złożonego systemu społeczno-ekologicznego do zmian, adaptacji i transformacji w odpowiedzi na zakłócenia (Goldstein, Wessells, Lejano, Butler, 2015). W badaniach odporności kładzie się nacisk na zapobieganie szokom, transformację oraz długoterminowe polityki antycypacyjne (Vale, 2014). Omawiana koncepcja bierze pod uwagę cztery wymiary rozwoju systemów. Należą do nich: wymiar przyrodniczy (Weichselgartner, Kelman, 2014; Torabi, Dedekorkut-Howes, Howes, 2018), ekonomiczny (Martin, Sunley, 2015), społeczny 
(Adger, 2000; Quinlan, Berbés-Blázquez, Haider, Peterson, 2016) oraz instytucjonalny (Bristow, Healy, 2014; Masik, 2018). Można zatem mówić o odporności przyrodniczej/ środowiskowej, ekonomicznej, społecznej i instytucjonalnej. Coraz bardziej istotnym zagadnieniem, jak wskazano wyżej, jest operacjonalizacja koncepcji odporności przez podejmowanie działań strategicznych oraz pomiar poziomu odporności. Z tego też względu celem opracowania jest przegląd międzynarodowych badań i na tej postawie przedstawienie stosowanych miar i wskaźników odporności.

\section{SKALE ODPORNOŚCI I RODZAJE WSKAŹNIKÓW}

Koncepcja odporności może się odnosić do skali globalnej, krajowej, regionalnej, miejskiej, sąsiedztwa oraz gospodarstwa domowego lub jednostki. Owe skale wpływają na podejmowane polityki i strategie, ponieważ różne rodzaje działań są odpowiednie dla różnych skal przestrzennych. Można wyróżnić zatem miary lub wskaźniki odpowiadające wyżej wymienionym skalom. Pomiar odporności może zostać dokonany ponadto w sposób bezpośredni i pośredni. Wskaźniki bezpośrednie mierzą odporność danego obszaru, odnosząc się do przeszłości i stanowią dobrą miarę w przypadku badania kryzysu czy katastrofy, które już miały miejsce. Wskaźniki pośrednie mierzą natomiast zakładaną odporność, jaka ma mieć miejsce w przyszłości, i mogą jedynie pośrednio wskazywać na niewielką lub większą odporność na zjawiska kryzysowe. Miary odporności mogą odnosić się również do wskaźników ilościowych oraz jakościowych. Te pierwsze najczęściej obejmują dane wtórne, dostępne w ramach statystyki publicznej. Te drugie dotyczą natomiast oceny wykorzystującej różne skale pomiaru na postawie badań ankietowych lub eksperckich grup fokusowych.

Wskaźniki w procesie prowadzenia polityki mogą odgrywać dwie zasadniczo różne role: mogą informować decydentów o podstawowych warunkach lub dostarczać informacji na temat wdrażania polityk i ich skuteczności. Wskaźniki podstawowe (kontekstowe) pomagają decydentom w opracowywaniu i wdrażaniu skuteczniejszych polityk. Jednak same nie wyrażają żadnego celu polityki (Cutter, Ash, Emrich, 2014; Figueiredo, Honiden, Schumann, 2018).

Wskaźniki oceniające polityki mogą być podzielone natomiast na cztery ogólne kategorie w zależności od tego, co jest mierzone: wskaźniki wejściowe (input indicators), wskaźniki produktu (output indicatiors), wskaźniki rezultatu (outcome indicatiors) i wskaźniki procesu (process indicators). Pierwszego rodzaju wskaźnik mierzy nakłady lub zasoby poświęcone na określoną politykę. Drugi rodzaj wskaźnika monitoruje wydajność i mierzy produkt danej polityki. Wskaźniki produktu mierzą dobra, które są wytwarzane przez politykę, aby osiągnąć jej cele. Nie mierzą jednak, jak bardzo skuteczna jest owa polityka. Z tego względu głównym celem wskaźników produktu jest monitorowanie, czy dane działanie/dana polityka są wydajne w kwestii tworzenia produktów. Trzeci rodzaj wskaźnika monitoruje skuteczność i informuje o rezultatach osiągniętych dzięki wdrożonym produktom. Wskaźniki rezultatu służą do monitorowania skuteczności polityk i pomagają zrozumieć, czy polityki są dobrze zaprojektowane pod kątem celów. Wskaźniki procesu informują natomiast o tym, czy i jakie działania zostały przedsięwzięte lub jakie procesy miały miejsce. Mogą one pomóc w określeniu, czy proces tworzenia polityki jest otwarty, włączający i zintegrowany. Wskaźniki procesu odnoszą się do instytucjonalnego wymiaru odporności, w tym do powszechnego 
uczestnictwa w zarządzaniu, oraz poziomu otwartości samorządów (Figueiredo, Honiden, Schumann, 2018).

\section{PRZYKŁADY WSKAŹNIKÓW W WYMIARZE GOSPODARCZYM}

Do przedstawienia przeglądu pomiarów odporności gospodarczej, ale także społecznej i instytucjonalnej, wzięto pod uwagę zarówno ogólnie zdefiniowane miary, jak i wskaźniki sensu stricto. Niektórzy autorzy bowiem podają te pierwsze, inni natomiast podają konkretne wskaźniki. Analizując wymiar makroekonomiczny oraz zasobów finansowych, należy stwierdzić, że większość miar i wskaźników dotyczy poziomu krajowego, część międzynarodowego i regionalnego (tabela 1). Wymiar ten odnosi się do międzynarodowego podziału pracy, ale też do polityki fiskalnej i monetarnej państwa. Najczęściej miarami bezpośrednimi określającymi stopień odporności są PKB i zatrudnienie. Dopiero w czasie kryzysu i po nim spadek wartości tych miar, gdy nie następuje szybki ich wzrost, informuje o niskim poziomie odporności.

W wymiarze mikroekonomicznym podejmowane polityki odnoszą się do sektorów gospodarczych, rynku pracy oraz firm (tabela 2). Z tego względu większość miar odnosi się do poziomu krajowego, regionalnego i lokalnego. Część miar jest miarami produktu, jeśli wynikają one z pojedynczych działań, część jest natomiast miarami rezultatu, jeśli wynikają z bardziej złożonych procesów bądź wielu działań o charakterze strategicznym lub politycznym (np. indeks specjalizacji przemysłowej Krugmana). Większość miar ma charakter pośredni, mniejsza część natomiast bezpośredni. Wszystkie miary mają charakter ilościowy, gdyż dane są zbierane na podstawie informacji udzielanych przez przedsiębiorstwa bądź instytucje publiczne.

Odporność gospodarcza w wymiarze innowacji i technologii jest mierzona z reguły na poziomie krajowym i regionalnym, choć czasem także lokalnym (tabela 3). Jednak to głównie strategie krajowe, odpowiednie finansowanie, prawodawstwo i zachęty podatkowe wpływają na wzrost znaczenia innowacji i sektora badawczo-rozwojowego dla budowania odporności gospodarczej. Nakłady na działalność rozwojową mają charakter wskaźników wejściowych, pozostałe wskaźniki są wskaźnikami produktu i rezultatu. Wszystkie miary sklasyfikowano jako miary pośrednie, mają one ponadto charakter ilościowy.

\section{MIARY I WSKAŹNIKI W WYMIARZE SPOŁECZNYM}

W ramach wymiaru społecznego ocenia się poziom kapitału społecznego, który obejmuje zagadnienia wsparcia społecznego, więzi społecznych, organizacyjnych, uczestnictwa obywateli w życiu społecznym, poczucia wspólnoty, lecz także kwestie odnoszące się do zdrowia. Oceniane są kompetencje społeczne, które odnoszą się do zdolności do organizowania się w celu identyfikowania i rozwiązywania nagłych problemów (Norris, Stevens, Pfefferbaum, Wyche, Pfefferbaum, 2008). Miary służące do opisu odporności społecznej obejmują z reguły poziom krajowy i są to miary rodzaju ilościowego. Natomiast dużo więcej niż dla wymiaru gospodarczego podaje się w literaturze wskaźników na poziomie lokalnym, sąsiedzkim i indywidualnym, które są wskaźnikami produktu lub rezultatu i które wówczas można jedynie uzyskać za pomocą pomiaru o charakterze jakościowym (tabela 4). 


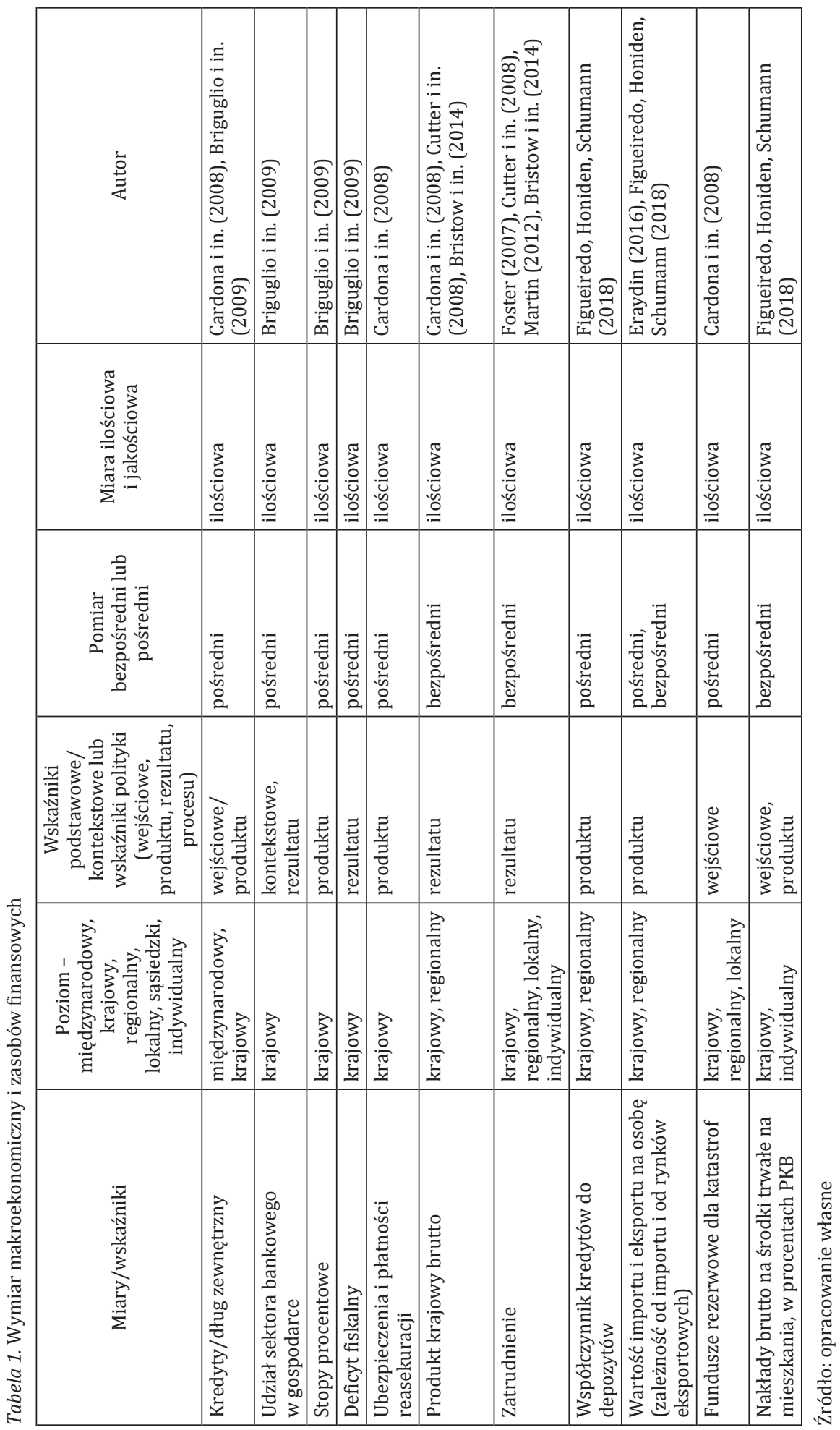




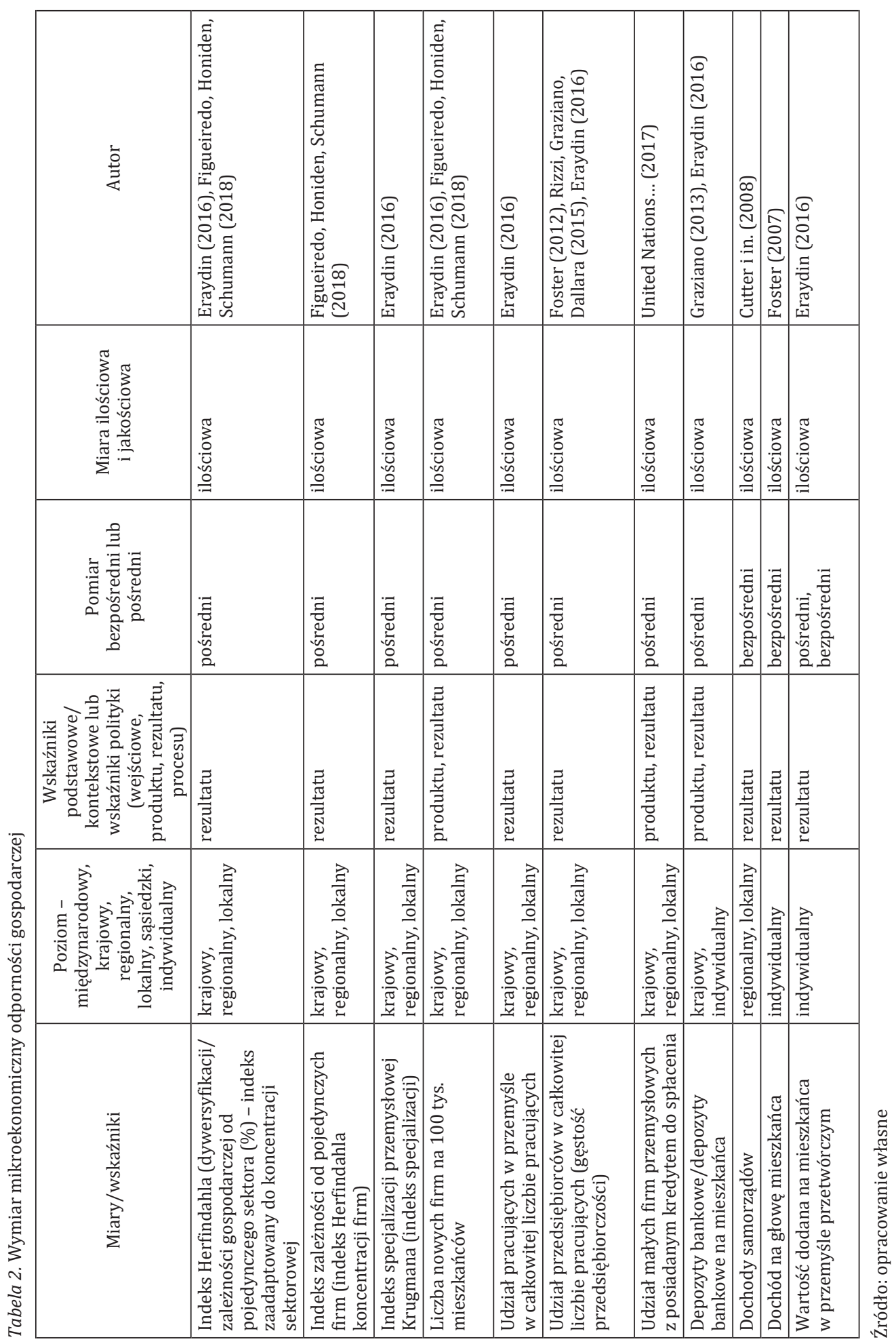




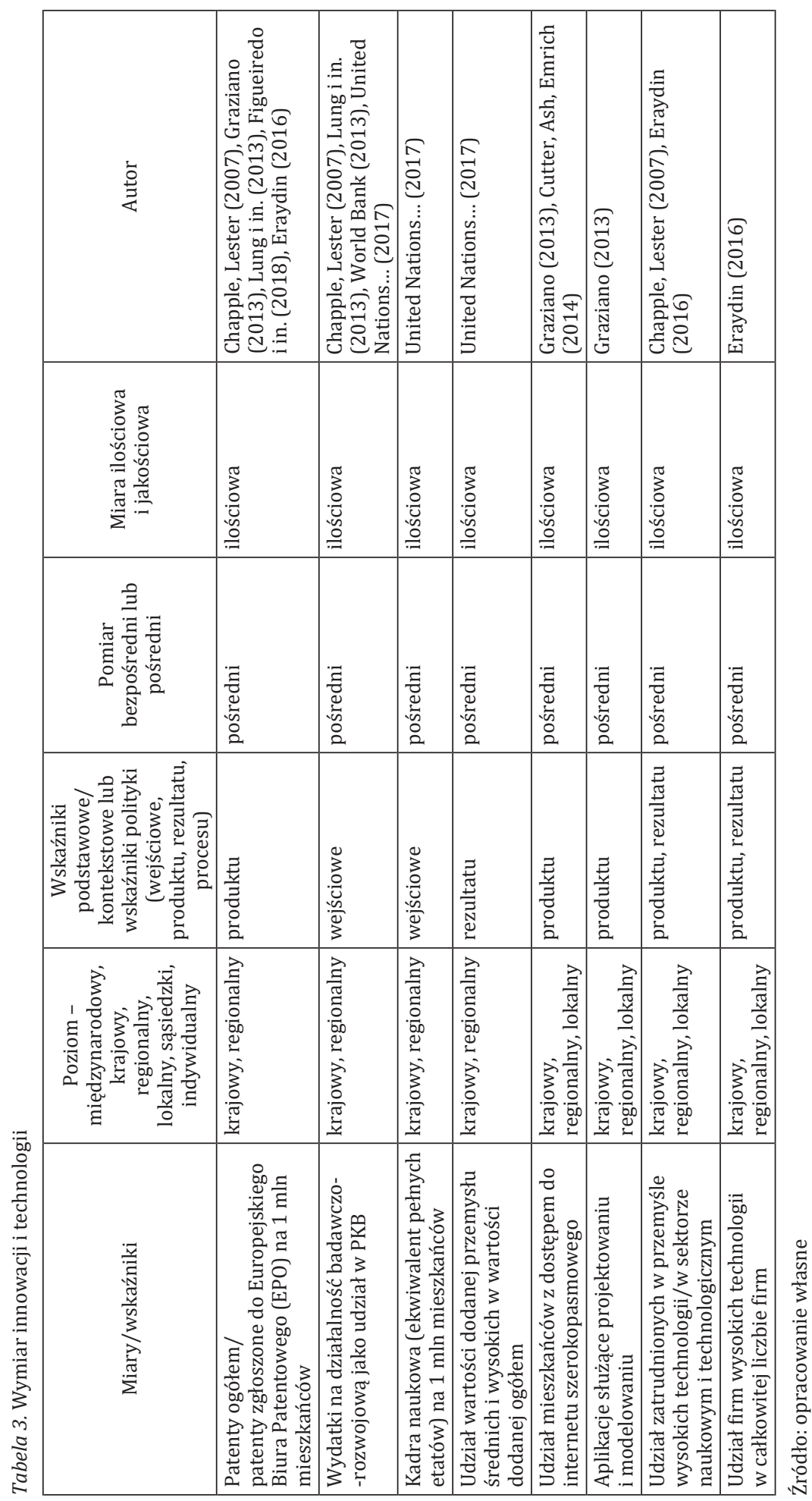




\begin{tabular}{|c|c|c|c|c|c|c|c|c|c|c|}
\hline 䓒 & 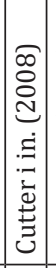 & 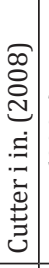 & 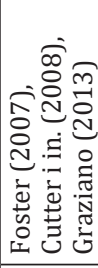 & 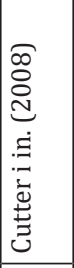 & 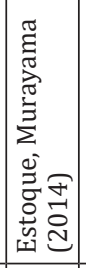 & 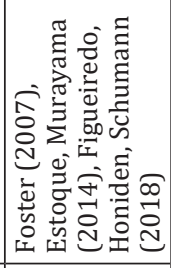 & 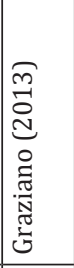 & 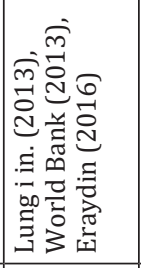 & 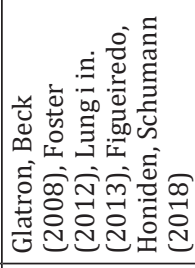 & 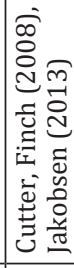 \\
\hline 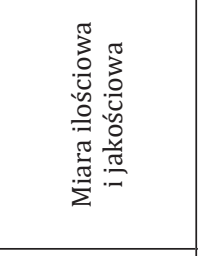 & 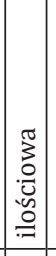 & 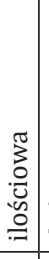 & 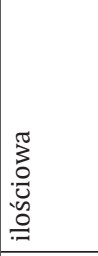 & 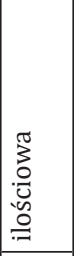 & 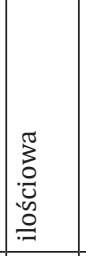 & 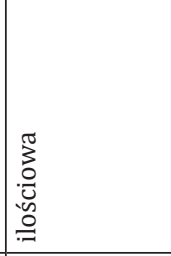 & 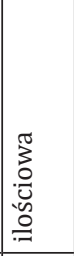 & 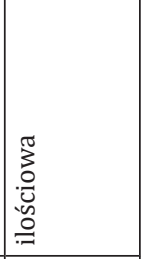 & 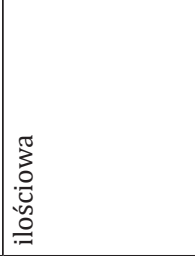 & 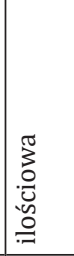 \\
\hline 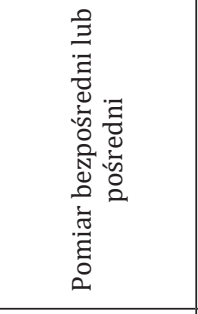 & 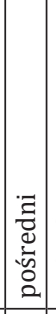 & 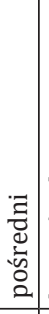 & 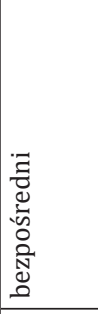 & 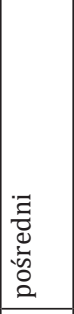 & 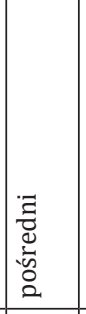 & 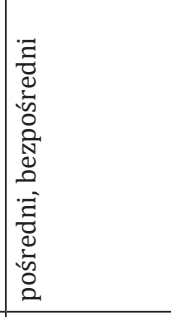 & 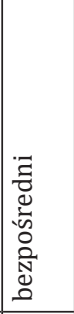 & 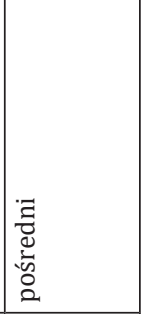 & 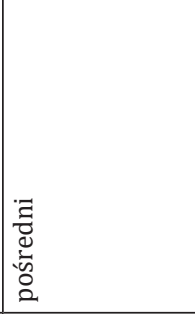 & 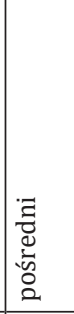 \\
\hline 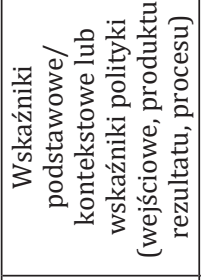 & 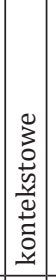 & 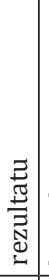 & 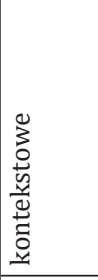 & 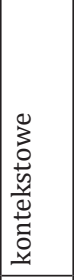 & 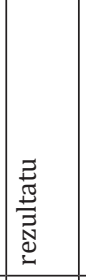 & 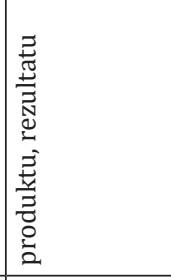 & 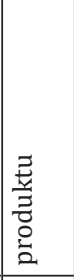 & 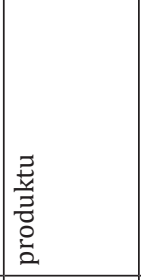 & 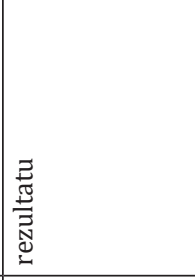 & 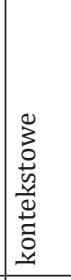 \\
\hline 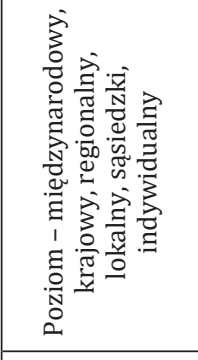 & 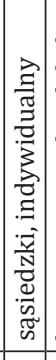 & 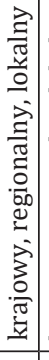 & 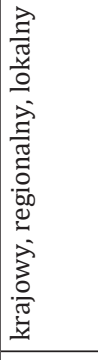 & 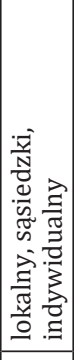 & 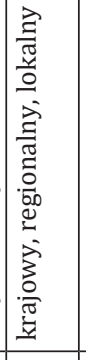 & 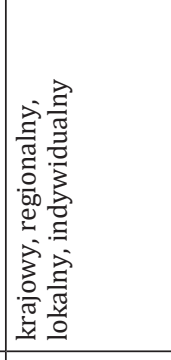 & 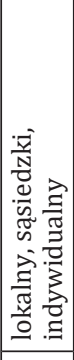 & 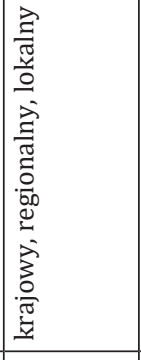 & 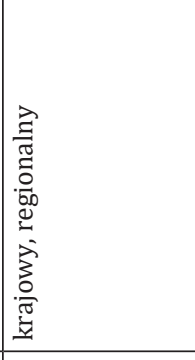 & 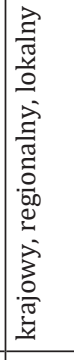 \\
\hline 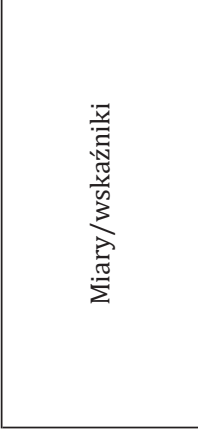 & 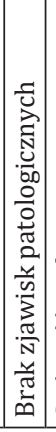 & 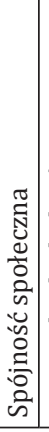 & 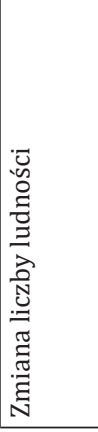 & 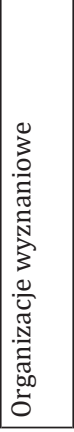 & 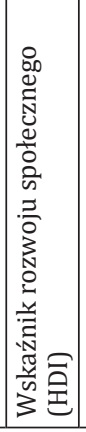 & 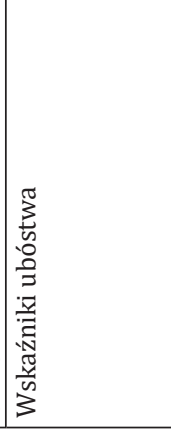 & 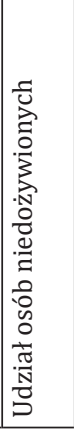 & 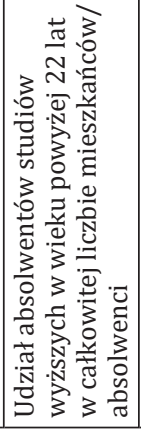 & 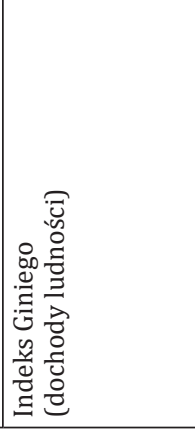 & 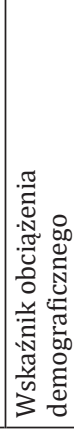 \\
\hline
\end{tabular}




\begin{tabular}{|c|c|c|c|c|c|c|c|c|c|}
\hline 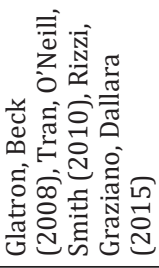 & 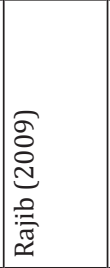 & 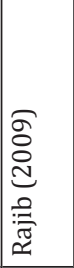 & 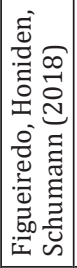 & 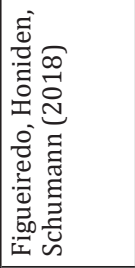 & 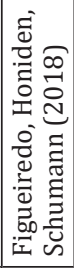 & 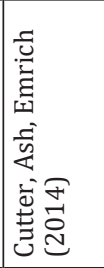 & 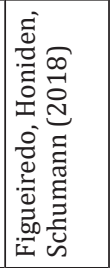 & 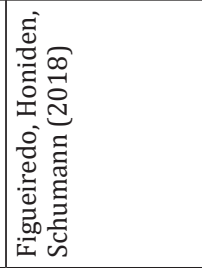 & 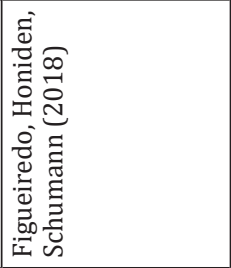 \\
\hline 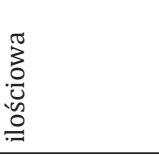 & 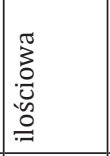 & 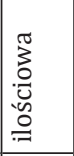 & 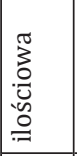 & 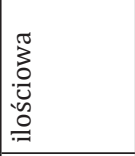 & 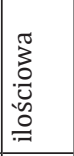 & 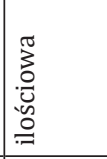 & 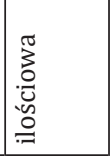 & 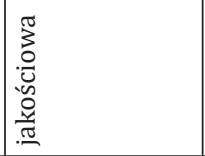 & 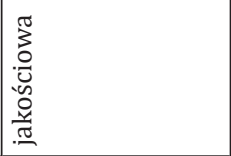 \\
\hline 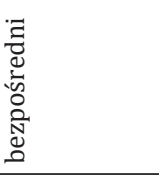 & 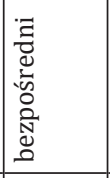 & 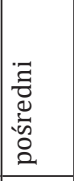 & 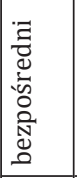 & 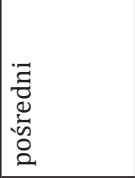 & 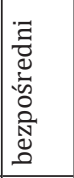 & 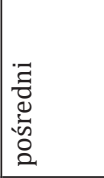 & 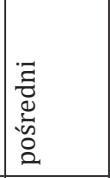 & 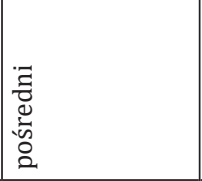 & 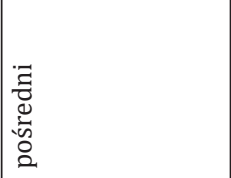 \\
\hline $\begin{array}{l}\frac{z}{z} \\
\frac{y}{z} \\
\text { t } \\
\text { t. }\end{array}$ & 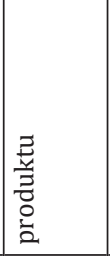 & 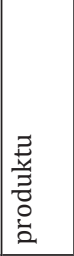 & 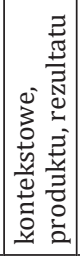 & 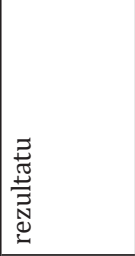 & 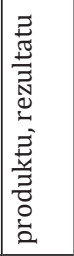 & 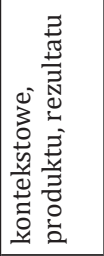 & 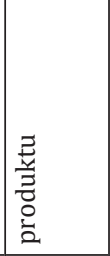 & 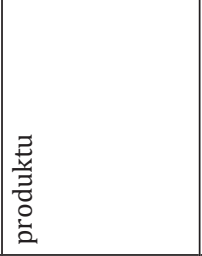 & 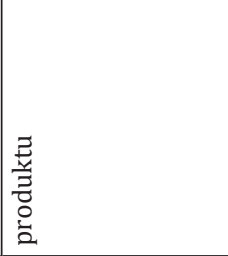 \\
\hline 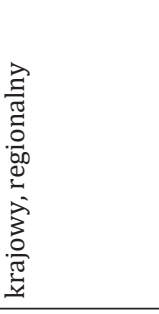 & 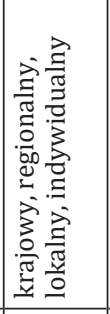 & 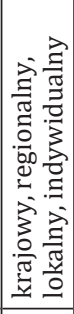 & 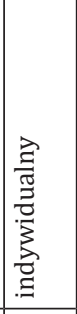 & 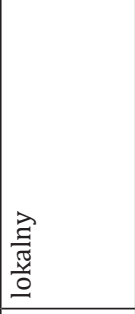 & 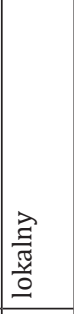 & 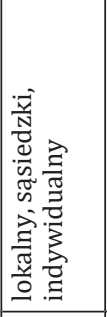 & 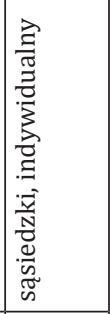 & 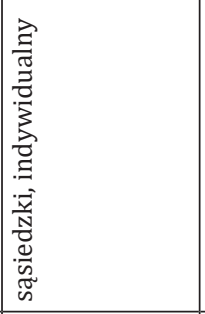 & 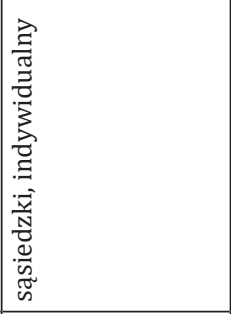 \\
\hline 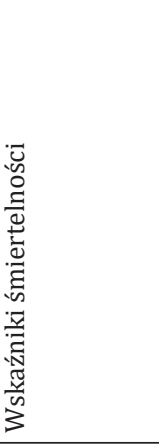 & 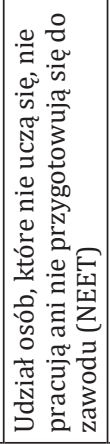 & 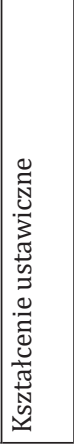 & 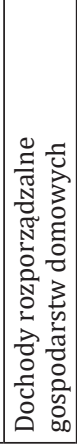 & 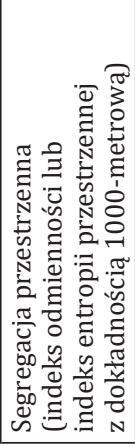 & 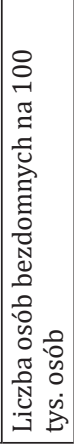 & 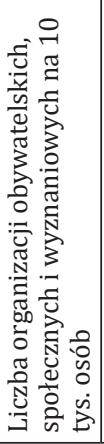 & 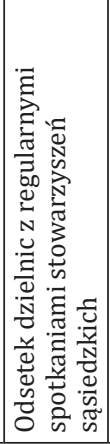 & 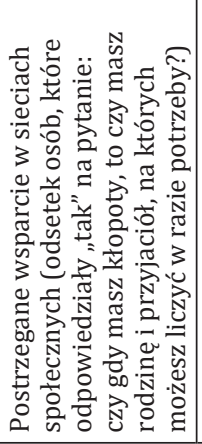 & 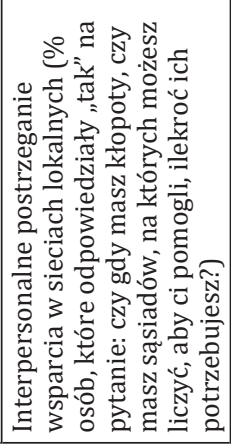 \\
\hline
\end{tabular}




\begin{tabular}{|c|c|c|c|c|c|c|c|}
\hline 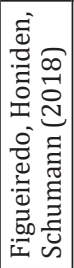 & 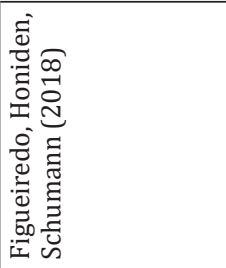 & 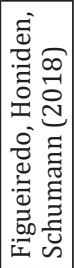 & 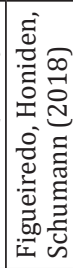 & 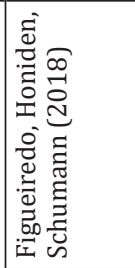 & 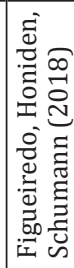 & 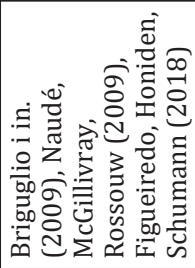 & 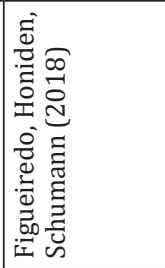 \\
\hline 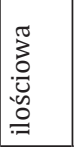 & 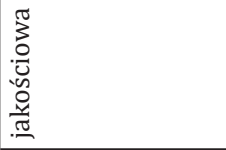 & 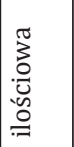 & 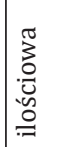 & 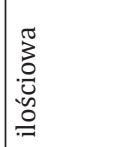 & 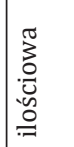 & 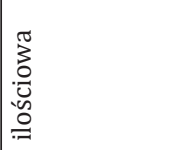 & 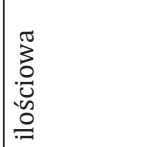 \\
\hline 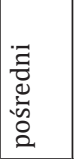 & 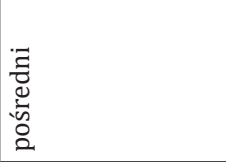 & 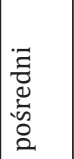 & 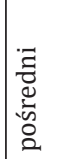 & 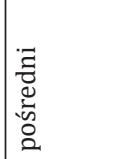 & 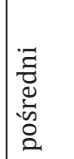 & 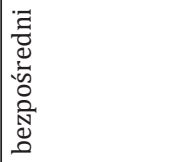 & 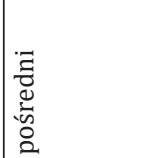 \\
\hline 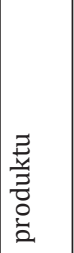 & 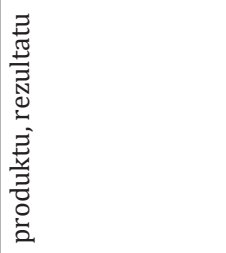 & 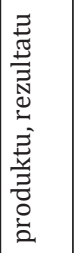 & 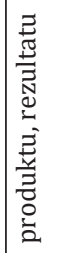 & 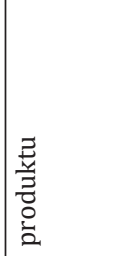 & 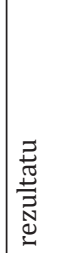 & 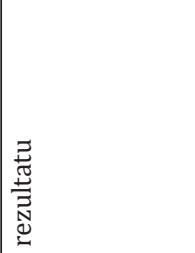 & 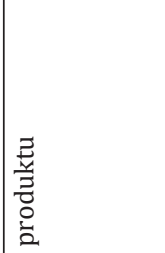 \\
\hline 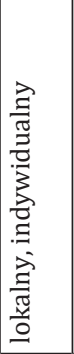 & 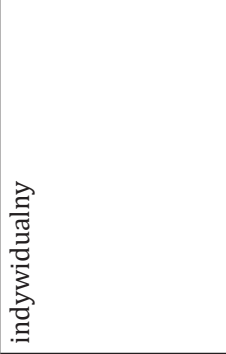 & 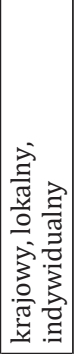 & 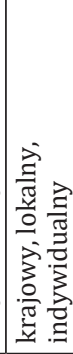 & 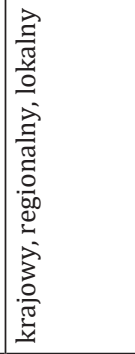 & 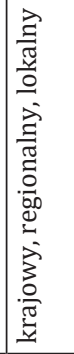 & 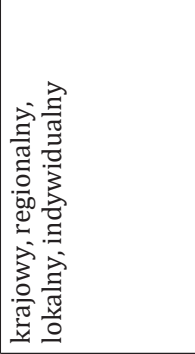 & 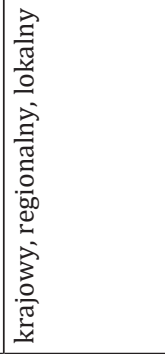 \\
\hline 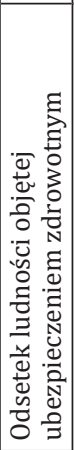 & 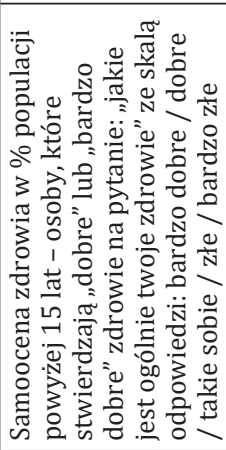 & 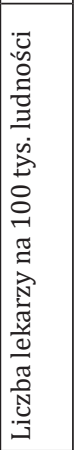 & 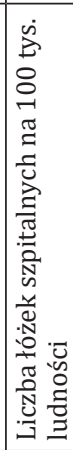 & 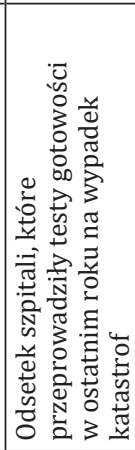 & 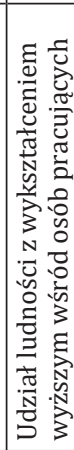 & 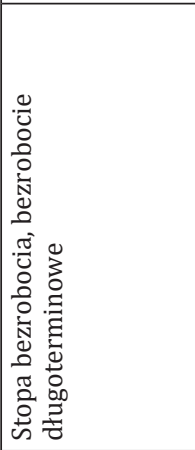 & 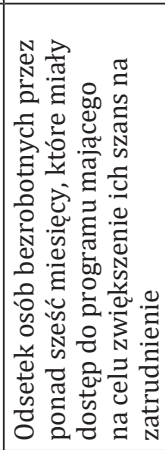 \\
\hline
\end{tabular}




\section{PRZYKŁADY MIAR I WSKAŹNIKÓW W WYMIARZE INSTYTUCJONALNYM}

Wymiar instytucjonalny dotyczy instytucji, organizacji i procesów decyzyjnych. Zdolność instytucjonalna jest niezbędna do reagowania na wstrząsy i powroty do stanu sprzed kryzysu (OECD, 2014a). Instytucje powinny zapewniać otwarte, przejrzyste i zintegrowane działania polityczne oraz umożliwiać skuteczne ich wdrażanie. Wymiar instytucjonalny odnosi się do umiejętności liderów do szybkiego dostosowywania się do zmian oraz do współpracy z innymi liderami. Zagadnienia w tym wymiarze obejmują także integrację i dzielenie się wiedzą pomiędzy różnymi interesariuszami oraz uczestnictwo w planowaniu. Istotne dla budowania odporności w wymiarze instytucjonalnym są też organizowane szkolenia na wypadek katastrof czy zagrożeń oraz współpraca z lokalnymi, krajowymi i międzynarodowymi instytucjami (Bec, Moyle, Moyle, 2019). Z tego względu sporo wskaźników obejmuje poziom krajowy, ale też lokalny i sąsiedzki. Dotyczą one konkretnych produktów i rezultatów, lecz także procesów jeśli mają charakter ciągły i systemowy. Większość wskaźników ponadto cechuje się pomiarem pośrednim i jest uzyskiwana metodami ilościowymi. Niektórzy autorzy w swoich badaniach jedynie sygnalizują zagadnienia (np. subkomponenty), które mogą się odnosić do odporności instytucjonalnej, nie podając miar czy wskaźników. Przykładem może być ogólnie sformułowane posiadanie planów czy poziom zaufania. Jednak z uwagi na ich szeroki kontekst badawczy, pozwalający lepiej zrozumieć istotę odporności instytucjonalnej, również je zamieszczono (tabela 5).

\section{DYSKUSJA I PODSUMOWANIE}

Przedstawione wyżej miary i wskaźniki stosowane są w badaniach w skali międzynarodowej, jak i poziomu krajowego lub niższego. Niektóre miary czy wskaźniki pozwalają mierzyć lepiej odporność w uboższych regionach świata, czego przykładem może być wskaźnik rozwoju społecznego, w którym istotną rolę odgrywa liczba lat edukacji. Również w tych regionach większe znaczenie mają organizacje wyznaniowe, gdyż w niewielkim stopniu rozwinięte są w nich inne (np. świeckie) instytucje społeczeństwa obywatelskiego.

Część wymienionych wskaźników jest dostępna i może być stosowana do porównań międzynarodowych, jak np. dochód rozporządzalny, produkt krajowy brutto czy wskaźnik obciążenia demograficznego. Część jednak powinna być stosowana jedynie na poziomie krajowym, czego przykładem mogą być dochody samorządów; różne bowiem są źródła finansowania składające się na pojęcie dochodów samorządów oraz różny jest zakres zadań i w związku z tym udział czy wielkość wydatków. Z kolei ograniczeniem dla stosowania i porównań wskaźników lokalnych i indywidualnych jest różna waga problemów lokalnych wpływająca na poziom odporności oraz znaczący koszt w przypadku stosowania miar jakościowych w oparciu o sondaże czy grupy fokusowe.

Najlepszymi wskaźnikami z uwagi na dostępność danych oraz ich porównywalność w różnych skalach przestrzennych są te, które biorą pod uwagę produkt krajowy, sektory gospodarcze, zatrudnienie i wskaźniki demograficzne, jak też różnego rodzaju indeksy, które zawierają większą i zestandaryzowaną ilość informacji. Jednak z uwagi na precyzyjność identyfikacji poziomu odporności w określonym kontekście lokalnym, np. miejskim, czy przydatność wskaźników do celów operacyjnych najbardziej wartościowe są wskaźniki poziomu sąsiedzkiego i lokalnego, szczególnie te, które są 


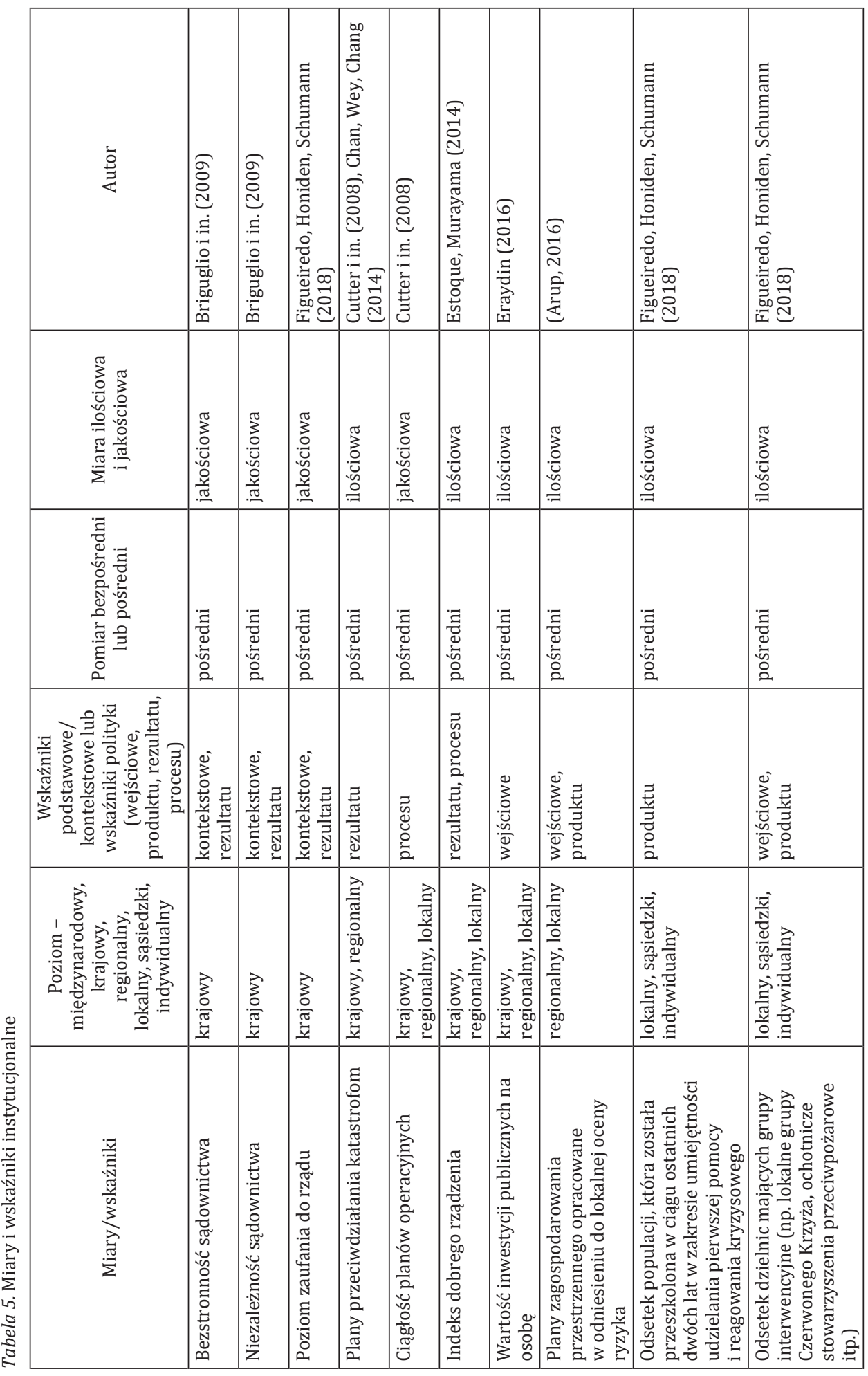




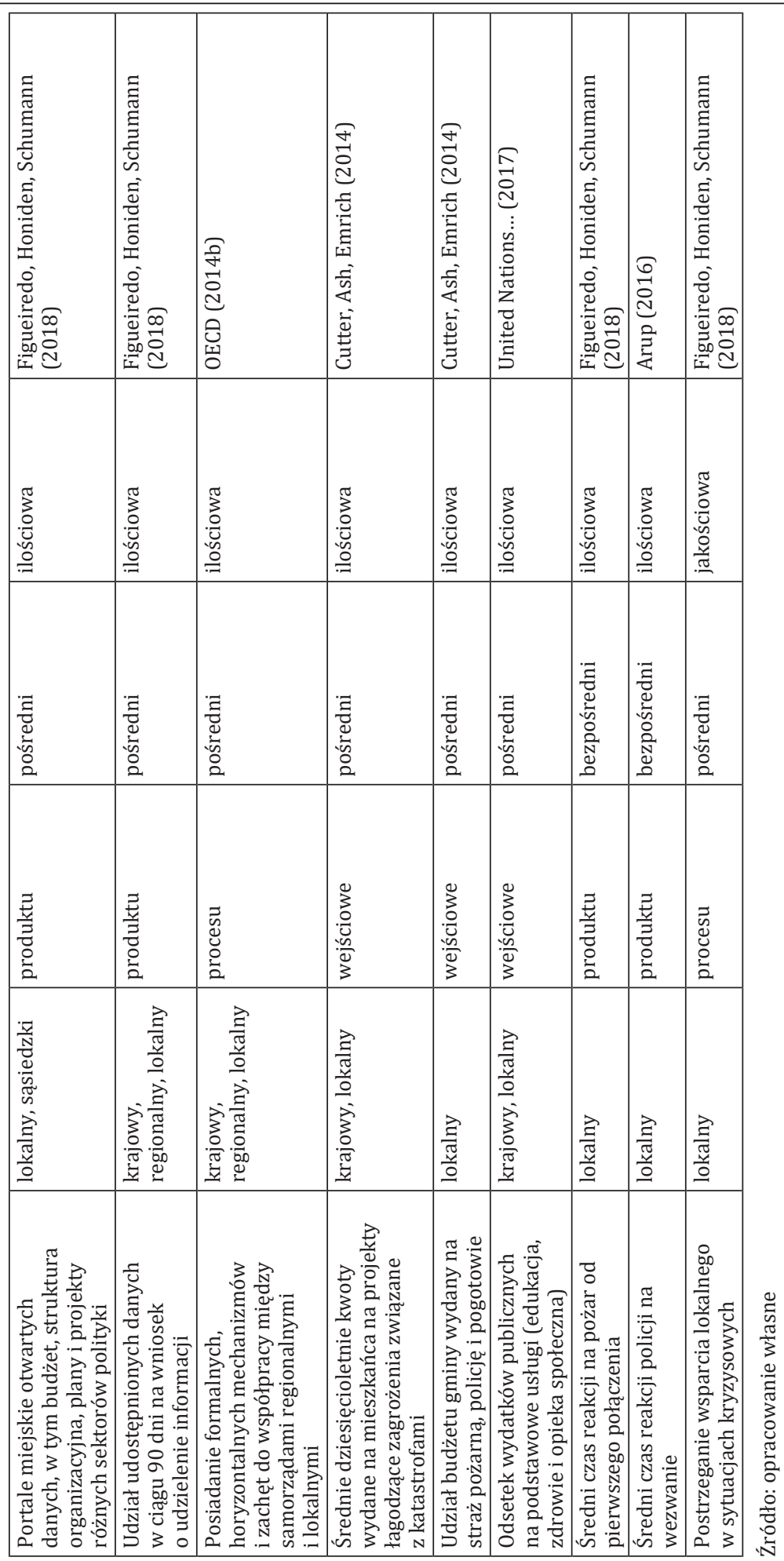


opracowywane w mieście tworzącym strategię odporności z udziałem odpowiednich grup eksperckich.

W artykule przedstawiono głównie te wskaźniki, które są często stosowane na świecie do badania odporności. Wybrano również te wskaźniki, które opracowano w ostatnich latach w celu monitorowania polityki odporności, w tym mierzenia adaptacyjności społeczności lokalnych oraz instytucji. Z przeprowadzonej kwerendy wynika, że najczęściej w literaturze międzynarodowej stosuje się wskaźniki opisujące wymiar gospodarczy. Odporność gospodarcza znajduje swój wyraz w licznych badaniach w skali międzynarodowej, krajowej i regionalnej. Zdecydowana większość wskaźników odporności gospodarczej pozwala na pomiar w sposób pośredni i są to zasadniczo miary ilościowe.

Nieco mniej miar i wskaźników dotyczy wymiaru społecznego. Więcej wyróżnia się tu wskaźników odpowiednich dla poziomu lokalnego, sąsiedzkiego i indywidualnego. W wymiarze społecznym dominują wskaźniki kontekstowe, produktu i rezultatu. Większość miar i wskaźników ma charakter pośredni. Natomiast częściej niż w przypadku odporności gospodarczej wykorzystuje się metody jakościowe.

Odporność instytucjonalna cechuje się ponownie większym znaczeniem wskaźników odpowiednich do pomiaru na poziomie krajowym, lecz także na poziomie lokalnym i sąsiedzkim. Można wyróżnić w tym wymiarze sporo wskaźników rezultatu i produktu, lecz również, co jest charakterystyczne dla odporności instytucjonalnej - wskaźniki procesu. Zdecydowana większość wskaźników odnosi się do pomiaru pośredniego, natomiast metody pomiaru mają charakter zarówno ilościowy, jak i jakościowy.

\section{Literatura}

References

Adger, W.N. (2000). Social and ecological resilience: are they related? Progress in Human Geography, 24, 347-364. doi: 10.1191/030913200701540465

Arup and The Rockefeller Foundation (2016). City Resilience Index: Understanding and Measuring City Resilience. Pozyskano z https://www.arup.com/perspectives/publications/research/ section/city-resilience-index

Bec, A., Moyle, Ch.J., Moyle, B.D. (2019). Community Resilience to Change: Development of an Index. Social Indicators Research, 142(3), 1103-1128. doi: 10.1007/s11205-018-1960-x

Briguglio, L., Cordina, G., Farrugia, N., Vella, S. (2009). Economic vulnerability and resilience: Concepts and measurements. Oxford Development Studies, 37, 229-247. doi: $10.1080 / 13600810903089893$

Bristow, G., Healy, A. (2014). Regional resilience: An agency perspective. Regional Studies, 48, 923-935. doi: 10.1080/00343404.2013.854879

Bristow, G., Healy, A., Norris, L., Kafkalas, G., Kakderi, Ch., Swash, A., Carey, H., Sagan, I., Masik, G., Wink, R., Kirchner, L., Koch, F., Speda, D., Sensier, M., Harding, A., Espenberg, K., Sepp, V., Varblane, U. (2014). ECR2 Economic Crisis: Resilience of Regions. ESPON Applied Research, Final Report.

Cardona, O.D., Ordaz, M.G., Carreño, M.L., Marulanda, M.C., Barbat, A.H. (2008). Fiscal impact of future earthquakes and country's economic resilience evaluation using the disaster deficit index. Referat wygłoszony na 14th World Conference on earthquake engineering, Beijing, China. Pozyskano z https://pdfs.semanticscholar.org/c1cc/d174ab69ab7b8c4a04d6baa496d05664c984.pdf

Chan, S.L., Wey, W.M., Chang, P.H. (2014). Establishing disaster resilience indicators for Tan-sui river basin in Taiwan. Social Indicators Research, 115(1), 387-418. doi: 10.1007/s11205012-0225-3 
Chapple, K., Lester, B. (2007). Emerging patterns of regional resilience. Working paper 2007-13 for the building resilient regions network. Berkeley: University of California.

Christopherson, S., Michie, J., Tyler, P. (2010). Regional resilience: Theoretical and empirical Perspectives. Cambridge Journal of Regions, Economy and Society, 3(1), 3-10. doi: 10.1093/ cjres/rsq004

Cutter, S.L., Ash, K.D., Emrich, C.T. (2014). The geographies of community disaster resilience. Global Environmental Change, 29, 65-77. doi: 10.1016/j.gloenvcha.2014.08.005

Cutter, S.L., Barnes, L., Berry, M., Burton, C., Evans, E., Tate, E., Webb, J. (2008). A place-based model for understanding community resilience to natural disasters. Global Environmenatal Change, 18, 598-606. doi: 10.1016/j.gloenvcha.2008.07.013

Cutter, S.L., Finch, C. (2008). Temporal and spatial changes in social vulnerability to natural hazards. Proceedings of the National Academy of Sciences of the United States of America, 105(7), 2301-2306. doi: 10.1073/pnas.0710375105.

Di Caro, P. (2014). Recessions, recoveries and regional resilience: Evidence on Italy. Cambridge Journal of Regions, Economy and Society, 8(2), 273-291. doi:10.1093/cjres/rsu029

Eraydin, A. (2016). The role of regional policies along with the external and endogenous factors in the resilience of regions. Cambridge Journal of Regions, Economy and Society, 9(1), 217-234. doi: 10.1093/cjres/rsv026

Estoque, R.C., Murayama, Y. (2014). Social-ecological status index: a preliminary study of its structural composition and application. Ecological Indicators, 43,183-194. doi: 10.1016/j. ecolind.2014.02.031

Figueiredo, L., Honiden, T., Schumann, A. (2018). Indicators for Resilient Cities. OECD Regional Development Working Papers, 2018/02, Paris: OECD Publishing. doi: 10.1787/6f1f6065-en

Foster, K. (2007). Case study approach to understanding regional resilience. Working paper 200807, Institute of Urban and Regional Development, Berkeley: University of California.

Foster, K. (2012). In search of regional resilience. W: M. Weir, H. Wial, H. Wolman (red.). Building regional resilience: urban and regional policy and its effects. Vol 4. Washington DC: Brookings Institution Press, 24-59.

Glatron, S., Beck, E. (2008). Evaluation of socio-spatial vulnerability of citydwellers and analysis of risk perception: industrial and seismic risks in Mulhouse. Natural Hazards and Earth System Sciences, 8(5), 1029-1040.

Goldstein, B.E., Wessells, T.A., Lejano, R., Butler, W. (2015). Narrating resilience: Transforming urban systems through collaborative storytelling. Urban Studies, 52, 1285-1303. doi: $10.1177 / 0042098013505653$

Gong, H., Hassink, R. (2017). Regional resilience: The critique revisited. W: N. Williams, T. Vorley (red.). Creating resilient economies: Entrepreneurship, growth and development in uncertain Times. Cheltenham: Edward Elgar, 206-216.

Graziano, P. (2013). Vulnerability and resilience of the economic, social and environmental dimensions of Italian provinces. Regional Studies Association, European Conference. Pozyskano z https://www.regionalstudies.org/wp-content/uploads/2018/07/Graziano2013.pdf

Jakobsen, K. (2013). Livelihood asset maps: a multidimensional approach to measuring risk-management capacity and adaptation policy targeting-a case study in Bhutan. Regional Environmental Change, 13(2), 219-233.

Lung, T., Lavalle, C., Hiederer, R., Dosio, A., Bouwer, L.M. (2013). Amulti-hazard regional level impact assessment for Europe combining indicators of climatic and non-climatic change. Global Environmental Change, 23, 522-536.

MacKinnon, D., Direckson, K. (2013). From resilience to resourcefulness: A critique of resilience policy and activism. Progress in Human Geography, 37, 253-270. doi:10.1177/0309132512454775

Martin, R. (2012). Regional economic resilience, hysteresis and recessionary shocks. Journal of Economic Geography, 12(1), 1-32. doi: 10.1093/jeg/lbr019

Martin, R.L., Sunley, P.J. (2015). On the notion of regional economic resilience: Conceptualisation and explanation. Journal of Economic Geography, 15, 1-42.

Masik, G. (2018). An agency perspective of resilience: the case of Pomorskie region. European Planning Studies, 26(5), 1060-1077. doi: 10.1080/09654313.2018.1436700 
Masik, G. (2019). Sektory gospodarcze w badaniach odporności ekonomicznej regionów. Prace Komisji Geografii Przemysłu Polskiego Towarzystwa Geograficznego, 33(1), 117-129. doi: $10.24917 / 20801653.331 .9$

Naudé, W., McGillivray, M., Rossouw, S. (2009). Measuring the vulnerability of subnational regions in South Africa. Oxford Development Studies, 37(3), 249-276.

Norris, F.H., Stevens, S.P., Pfefferbaum, B., Wyche, K.F., Pfefferbaum, R.L. (2008). Community resilience as a metaphor, theory, set of capacities, and strategy for disaster readiness. American Journal of Community Psychology, 41(1-2), 127-150.

OECD (2014a). Overview paper on resilient economies and societies. Paris: OECD. Pozyskano z https://www.oecd.org/mcm/C-MIN(2014)7-ENG.pdf

OECD (2014b). Recommendation of the Council on Effective Public Investment Across Levels of Government. Paris: OECD. Pozyskano z https://www.oecd.org/regional/regional-policy/ Principles-Public-Investment.pdf

Pike, A., Dawley, S., Tomaney, J. (2010). Resilience, adaptation and adaptability. Cambridge Journal of Regions, Economy and Society, 3(1), 59-70. doi: 10.1093/cjres/rsq001

Quinlan, A.E., Berbés-Blázquez, M., Haider, L.J., Peterson, G.D. (2016). Measuring and assessing resilience: broadening understanding through multiple disciplinary perspectives. Journal of Applied Ecology, 53, 677-687.

Rachwał, T. (2011). Wpływ kryzysu na zmiany produkcji przemysłowej w Polsce. Prace Komisji Geografii Przemysłu Polskiego Towarzystwa Geograficznego, 17, 99-113.

Rajib, S. (2009). City profile: climate and disaster resilience. United Nations University (UNU), Citynet (CITYNET), United Nations Office for Disaster Risk Reduction-Hyogo Liaison Office (UNISDR Hyogo), Asia Regional Task Force on Urban Risk Reduction (RTF-URR). Pozyskano z https://www.unisdr.org/files/8168_cityprofilelowresolution.pdf

Rizzi, P., Graziano, P., Dallara, A. (2015). The regional competitiveness: an alternative approach. Rivista Internazionale di Scienze Sociali, 130(3), 307-366.

Simmie, J., Martin, R. (2010). The economic resilience of regions: towards an evolutionary approach. Cambridge Journal of Regions, Economy and Society, 3(1), 27-43. doi: 10.1093/cjres/ rsp029

Torabi, E., Dedekorkut-Howes, A., Howes, M. (2018). Adapting or maladapting: Building resilience to climate-related disasters in coastal cities. Cities, 72, 295-309. doi: 10.1016/j.cities.2017.09.008

Tran, L, O'Neill, R.V., Smith, E.R. (2010). Spatial pattern of environmental vulnerability in the MidAtlantic region. USA. Applied Geography, 30(2), 191-202. doi: 10.1016/j.apgeog.2009.05.003

United Nations, Economic and Social Council, Statistical Commission (2017). Report of the InterAgency and Expert Group on Sustainable Development Goal Indicators. E/CN.3/2017/2, Annex III. Pozyskano z https://unstats.un.org/sdgs/indicators/Official\%20Revised\%20 List $\% 20$ of\%20global\%20SDG\%20indicators.pdf

Vale, L.J. (2014). The Politics of Resilient Cities: Whose Resilience and Whose City? Building Research \& Information, 42(2), 191-201. doi: 10.1080/09613218.2014.850602.

Weichselgartner, J., Kelman, I. (2014). Geographies of resilience Challenges and opportunities of a descriptive concept. Progress in Human Geography, 39(3), 249-267. doi: $10.1177 / 0309132513518834$.

WMO Statement on the State of the Global Climate in 2018 (2019). World Meteorological Organization, No. 1233, Geneva. Pozyskano z https://library.wmo.int/doc_num.php?explnum_id=5789

World Bank (2013). World Development Report 2014: Risk and Opportunity-Managing Risk for Development. Washington DC: World Bank. Pozyskano z https://openknowledge.worldbank.org/handle/10986/16092

Zioło, Z., Rachwał, T. (red.) (2011a). Wpływ kryzysu na zachowania przedsiębiorstw oraz przemiany struktur regionalnych. Prace Komisji Geografii Przemysłu Polskiego Towarzystwa Geograficznego, 17.

Zioło, Z., Rachwał, T. (red.) (2011b). Przemiany struktur lokalnych i regionalnych sektora usług w latach kryzysu gospodarczego. Prace Komisji Geografii Przemysłu Polskiego Towarzystwa Geograficznego, 18. 
Zioło, Z., Rachwał, T. (red.) (2014). Przemiany struktur regionalnych w warunkach kryzysu gospodarczego. Prace Komisji Geografii Przemysłu Polskiego Towarzystwa Geograficznego, 26.

Grzegorz Masik, dr, Uniwersytet Gdański, Wydział Oceanografii i Geografii, Instytut Geografii, Zakład Geografii Społeczno-Ekonomicznej. Zatrudniony jest na Uniwersytecie Gdańskim na stanowisku adiunkta. Realizował m.in. projekty dla OECD i ESPON. Jego zainteresowania badawcze obejmują warunki i jakość życia ludności, procesy suburbanizacji, koncepcję miasta inteligentnego, politykę lokalną i regionalną, w tym koncepcję odporności oraz zastosowanie geograficznych systemów informacyjnych w geografii społeczno-ekonomicznej.

Grzegorz Masik, PhD, University of Gdańsk, Faculty of Oceanography and Geography, Institute of Geography, Department of Socio-Economic Geography. He is employed at the University of Gdańsk as an associate professor. He has conducted projects for OECD and ESPON. His research interests include the conditions and quality of life of the population, suburbanisation processes, the concept of smart city, local and regional policy including the concept of resilience and the application of geographical information systems in socio-economic geography.

ORCID: 0000-0001-6019-7763

\section{Adres/address:}

Uniwersytet Gdański, Wydział Oceanografii i Geografii Instytut GeografiiZakład Geografii Społeczno-Ekonomicznej ul. Bażyńskiego 4, 80-309 Gdańsk, Polska

e-mail: geogm@ug.edu.pl 